\title{
Effects of pre-wetting aggregate on the properties of mortars made with recycled concrete and lightweight aggregates
}

\section{Efeito da pré-molhagem do agregado nas propriedades das argamassas com agregado reciclado de concreto e agregado leve}

\author{
Lidiane Fernanda Jochem ${ }^{1}$, Diego Aponte ${ }^{2}$, \\ Marilda Barra Bizinotto ${ }^{2}$, Janaíde Cavalcante Rocha ${ }^{1}$
}

\footnotetext{
${ }^{1}$ Federal University of Santa Catarina. Department of Civil Engineering, CEP 88.040-900, Florianópolis, Santa Catarina, Brazil.

${ }^{2}$ Polytechnic University of Catalonia. Department of Construction Engineering, 08034, Barcelona, Catalonia, Spain. e-mail: lidijochem@gmail.com,diego.fernando.aponte@upc.edu,marilda.barra@upc.edu, janaide.rocha@ufsc.br
}

\begin{abstract}
This paper examines the suitability of partially replacing natural aggregate, sand, (NA) with recycled concrete aggregate (RCA) or lightweight aggregate (LWA) in mortars, under the hypothesis that pre-wetting aggregates would produce improvement in mortar properties. Fresh mortar properties such as density, entrained air content, consistency and heat of hydration, as well as hardened mortar properties such as dry density, compressive and flexural strength, and dimensional instability at $0 \%$ and $100 \%$ saturation were determined. The results show that mortars made with natural aggregate $(75 \%)$ and recycled concrete aggregate $(25 \%)$ have similar properties to mortars made with only natural aggregate (100\%) and that pre-wetting the aggregates does not influence the properties of mortars significantly. Therefore, partial replacement with recycled concrete aggregate is a viable alternative for producing mortar.
\end{abstract}

Keywords: pre-wetting, recycled concrete aggregate, lightweight aggregate, mortars, sustainability.

\section{RESUMO}

Este artigo buscou verificar a substituição parcial do agregado natural, areia (NA) por agregado de concreto reciclado (RCA) ou agregado leve (LWA) em argamassas, sob a hipótese que agregados pré-molhados produziriam melhoras nas propriedades da argamassa. Para isso, avaliou-se as propriedades das argamassas no estado fresco, como massa específica, teor de ar incorporado, consistência e calor de hidratação, bem como as propriedades no estado endurecido, como massa específica, resistência à compressão e à flexão, e instabilidade dimensional, com $0 \%$ e $100 \%$ de saturação. Os resultados mostram que as argamassas preparadas com agregado natural $(75 \%)$ e agregado de concreto reciclado $(25 \%)$ possuem propriedades semelhantes às argamassas preparadas com apenas agregado natural (100\%) e que a pré-molhagem dos agregados não influenciou significativamente as propriedades das argamassas. Assim, constatou-se que, a substituição parcial do agregado natural por agregado de concreto reciclado é uma alternativa viável para a produção de argamassa.

Palavras-chave: pré-molhagem, agregado de concreto reciclado, agregado leve, argamassa, sustentabilidade.

\section{INTRODUCTION}

Sustainability issues such as the environment, solid waste disposal areas, and natural resource depletion are now major concerns, pointing to a growing need for further research. Thus, the use of fine recycled aggregate is of great interest since, according to ANGULO et al. [1], recycling plants generate a large amount of fine aggregate (less than $4.8 \mathrm{~mm}$ ), representing nearly $50 \%$ of the weight of the crushed recycled aggregate used 
to manufacture coarse recycled aggregate. For a long time, it was believed that fine fractions of recycled aggregate had low quality properties, so they were discarded [2]. However, recent studies have shown that the properties of fine recycled concrete aggregate do not differ significantly from those of coarse fractions and that the use of the former can bring benefits to the final material and the environment [3-8].

Lightweight aggregates improve the quality of the Interfacial Transition Zone (ITZ) because their porosity absorbs water from the paste, reducing the water film around the aggregate [9]. Therefore, recycled aggregate can also improve the ITZ thanks to its absorption capacity and rough surface, which helps the cement paste to better interact with the aggregate, similarly to lightweight aggregates.

Using fine recycled aggregate in mortars instead of natural aggregates leads to increased shrinkage due to its high absorption capacity. Additionally, its cement paste content and cracks result in lower resistance and, consequently, reduced mechanical strength. However, the use of pre-wetting fine recycled aggregate can alleviate these problems. There are few studies on pre-wetting of fine recycled aggregates intended for mortars $[3,10,11,8]$. In general, this method is still considered detrimental to the properties of the final material, so its use is avoided. Moreover, the higher water consumption of mortars prepared with recycled aggregates is usually compensated for by limiting the use of finite raw materials, such as natural aggregates.

This paper aims to analyze the effect of partially replacing natural aggregate with recycled aggregate (RCA) or lightweight aggregate (LWA) and of these pre-wetting aggregates on the properties of fresh and hardened mortars.

\section{MATERIALS AND METHODS}

\subsection{Materials}

Mortar was produced with a cement CEM II/B- 32.5 N (limestone Portland cement), with density of 3.10 $\mathrm{g} / \mathrm{cm}^{3}$ was used.

Three different types of aggregates were used: recycled concrete aggregate (RCA), commercially available lightweight expanded clay aggregate (LWA), named Leca by the producer, and natural aggregate (NA). The recycled concrete aggregate was composed of crushed concrete blocks and mortar whereas the natural aggregate was of siliceous origin. In order to obtain a fine aggregate (less than $4.8 \mathrm{~mm}$ size aggregates) a coarse aggregate from waste concrete was reduced in a jaw crusher. Lightweight aggregate was used in order to compare the effects of porosity. For all mortar the grain size aggregates (NA, LWA and RCA) was the same.

The granulometric curve for the three aggregates was prepared in the laboratory, with $20 \%$ of each fraction $(2.4 ; 1.2 ; 0.6 ; 0.3 ; 0.15 \mathrm{~mm})$, with no fraction less than $0.15 \mathrm{~mm}$. Fractions 0.3 and $0.15 \mathrm{~mm}$ corresponded to the natural aggregate in all mixtures. Replacement of natural aggregate by recycled or lightweight aggregates was $25 \%$. Replaced fractions $(2.4 \mathrm{~mm}, 1.2 \mathrm{~mm}$, and $0.6 \mathrm{~mm})$ followed proportions $8.5 \%, 8.5 \%$, and $8 \%$, respectively. To ensure that fractions less than $0.15 \mathrm{~mm}$ were not present, all the fractions were washed through a specific sieve.

\subsection{Mixture compositions}

Mortars had two ratios between cement and aggregates, i.e. 1: 2.5 and 1: 3 (weight), and similar size distributions. Due to large variation in aggregate properties mortar mixes were produced to the same consistency (flow table). Reference mortar was produced with a/c ratio of 0.42 .

LWA and RCA were incorporated by replacing equal volumes of the normal weight natural aggregate at appropriate gradations to ensure minimum alteration of the overall gradation of the aggregate (Table 1).

Table 1: Mortar compositions

\begin{tabular}{|l|c|c|c|c|c|}
\hline \multirow{2}{*}{ Mortars } & \multicolumn{3}{|c|}{ Aggregates } & $\begin{array}{c}\text { Effective wa- } \\
\text { ter to cement } \\
\text { ratio }\end{array}$ & $\begin{array}{c}\text { Cement to } \\
\text { aggregate to } \\
\text { water ratio }\end{array}$ \\
\cline { 2 - 5 } & Natural & Recycled & Lightweight & 0.42 & \multirow{2}{*}{$1: 2.5: 0.42$} \\
\hline NA-2.5 & $100 \%$ & - & - & 0.29 & \\
\hline LWA-2.5 & $75 \%$ & - & $25 \%$ & 0.39 & \\
\hline RCA-2.5 & $75 \%$ & - & $25 \%$ & \\
\hline
\end{tabular}




\begin{tabular}{|c|c|c|c|c|c|}
\hline RCA + PS-2.5 & $75 \%$ & $25 \%$ & - & & \\
\hline NA-3 & $100 \%$ & - & - & 0.42 & \multirow{5}{*}{ 1: $3: 0.42$} \\
\hline LWA-3 & $75 \%$ & - & $25 \%$ & \multirow{2}{*}{0.29} & \\
\hline LWA + PS-3 & $75 \%$ & - & $25 \%$ & & \\
\hline RCA-3 & $75 \%$ & $25 \%$ & - & \multirow{2}{*}{0.39} & \\
\hline $\mathrm{RCA}+\mathrm{PS}-3$ & $75 \%$ & $25 \%$ & - & & \\
\hline
\end{tabular}

Note: $\mathrm{NA}=$ natural aggregate; LWA = lightweight aggregate; RCA = recycled aggregate; $\mathrm{PS}$ = pre-wetting aggregate in a saturated surface-dry condition used to prepare the mortars.

The natural aggregate was used in a dry state whereas the recycled and lightweight aggregates were used in a pre-dry state for some mortars and in a saturated surface-dry condition (pre-wetting - PS) for others. Pre-wetting was achieved by keeping the recycled and lightweight aggregates in watertight containers for 24 hours. Aggregate saturation was based on their granular absorption capacity and accomplished by immersion in water for 24 hours. The water used in this process was reduced from the total amount of water of the composition. Thus, the sum of the water necessary to saturate the aggregate and the kneading water was the same w/c ratio (0.42) of mortars prepared with dried aggregates. The water content required to saturate the aggregate was calculated as the product between the amount of aggregate and the grain absorption rate, and was subsequently added to the grain. In consequence, there was no free water because 24 hours after the aggregate came in contact with the water, all the initial surface water had been absorbed.

All mixtures were prepared in a conventional mortar mixer according to standard NBR 16541 [12].

Prisms of $40 \mathrm{~mm}$ x $40 \mathrm{~mm}$ x $160 \mathrm{~mm}$ were produced for flexural and compressive strength tests performed at 3, 28 and 90 days, whereas prisms of $25 \mathrm{~mm} \times 25 \mathrm{~mm}$ x $285 \mathrm{~mm}$ were produced for dimensional instability tests performed at 1, 2, 3, 7, 14, 21, 28, 42, 56, 70, 84, 98 and 120 days. All tests were conducted in triplicate.

Mortar specimens were demolded and sealed in plastic wrap and aluminum paper and cured under $94 \%$ relative humidity at $23{ }^{\circ} \mathrm{C}$ until the test ages.

\subsection{Methods}

Density and water absorption capacity of aggregates were calculated according to standard EN 1097-6 [13]. Unit weight tests and void ratio were based on standard NBR NM 45 [14].

Density and entrained air content [15], consistency [16] and heat of hydration [17] were determined for mortars in the fresh state. For mortars in the hardened state, density [18], mechanical strength [19] and dimensional instability [20] were calculated.

The test results were statistically analyzed. Analysis of variance (ANOVA) was performed to identify possible differences between averages resulting from partial replacement of the natural aggregate with the lightweight and recycled aggregates, and to evaluate the efficiency of the pre-wetting procedure and the ratios (1: 3 and 1:2.5). The F-test in ANOVA was used to determine possible statistically significant differences between the mean values of the properties studied. If the $\mathrm{p}$-value of the F-test is less than 0.05 , it has a significant effect on the property under analysis at a $95 \%$ confidence level; if it is more than 0.05 , its effect is insignificant. The analysis of variance determines differences between the means, but it does not indicate which mean differs from which. For this reason, the Duncan test was performed, as it allows comparing the means and defining which samples are the same and which are different. The tables summarizing the Duncan test results show the homogeneous groups, where identical samples have the 'equal' symbol in the same group.

\section{RESULTS AND DISCUSSION}

\subsection{Properties of aggregates}

The results of the physical properties of the aggregates are given in Table 2. As can be seen, density, unit weight, and void ratio are influenced by the nature of the aggregates. That is why the lightweight aggregate and the natural aggregate had the highest and lowest porosity, respectively.

The absorption capacity of the recycled aggregate $(5 \%)$ is in agreement with the $6 \%$ absorption capacity observed for recycled concrete aggregate by SIDOROVA et al. [9], and is within the limit stipulated by standard NBR 15116 [21] of less than $12 \%$ for concrete without structural function. According to PEDRO et al. [22], high quality recycled aggregate has the best performance for very small pores (smaller than 0.1 
$\mu \mathrm{m})$ and a water absorption capacity lower than $7 \%$.

Aggregates were also chemically evaluated for chlorides $\left(\mathrm{Cl}^{-}\right)$and sulfates $\left(\mathrm{SO}_{4}{ }^{2-}\right)$. The lightweight aggregate and the recycled aggregate contained 13.9 and $0.8 \mathrm{mg} / \mathrm{kg}$ chlorides and 9.4 and $12.9 \mathrm{mg} / \mathrm{kg}$ sulfates, respectively.

Table 2: Physical properties of aggregates.

\begin{tabular}{|c|c|c|c|c|c|}
\hline Aggregates & $\begin{array}{c}\text { Density } \\
\left(\mathbf{g} / \mathbf{c m}^{\mathbf{3}}\right)\end{array}$ & $\begin{array}{c}\text { Unit weight } \\
\left(\mathbf{g} / \mathbf{c m}^{\mathbf{3}}\right)\end{array}$ & $\begin{array}{c}\text { Void ratio } \\
(\mathbf{\%})\end{array}$ & $\begin{array}{c}\text { Absorption } \\
\mathbf{2 4} \mathbf{h}(\boldsymbol{\%})\end{array}$ & $\begin{array}{c}\text { Sieve size frac- } \\
\text { tion }\left(\mathbf{D}_{\mathbf{i}} / \mathbf{d}_{\mathbf{i}}\right)\end{array}$ \\
\hline NA & 2.64 & 1.66 & 37.1 & 0.5 & $2.4 / 0.15 \mathrm{~mm}$ \\
\hline RCA & 2.54 & 1.30 & 48.8 & 5.0 & $2.4 / 0.6 \mathrm{~mm}$ \\
\hline LWA & 1.18 & 0.32 & 72.8 & 41.3 & $2.4 / 0.6 \mathrm{~mm}$ \\
\hline
\end{tabular}

\subsection{Physical properties of fresh mortars}

The physical properties of mortars in the fresh state with ratios 1:3 and 1:2.5 are shown in In terms of consistency, the pre-wetting procedure had little influence on the making of mortars with ratio of $1: 3$, while for mortars with ratio of 1: 2.5 , paste consistency increased with the use of pre-wetting aggregates (Table 4). Additionally, mortars with ratio of 1:2.5 had higher consistency, as expected with the decreased aggregate content and increased cement content. Consistency of mortars with ratio of 1:3 decreased considerably when lightweight aggregate was incorporated into the paste and it consumed part of the water of the mixture due to its high absorption capacity, impairing consistency of specimens. The effective w/c ratio was lower than that of the other mortars, even when using pre-wetting lightweight aggregate, due to the great absorption capacity of this material. Natural aggregate mortars had greater consistency for both $w / c$ ratios.

Table 3. Based on ANOVA ( $p$-value of the $F$-test was lower than 0.05 ) and at a $95 \%$ confidence level, it can be observed that partial replacement of the aggregate, the pre-wetting procedure and the ratio used affected density, entrained air content, and consistency of mortars significantly.

Regarding density, the Duncan test results (Table 4) indicate that lightweight aggregate specimens with ratio of 1:3 do not differ among themselves (homogeneous group 1) and neither do NA, RCA and RCA+PS specimens with 1:2.5 ratio, (homogeneous group 2), whereas the other mortars do differ from each other. Such parity between NA, RCA and RCA+PS specimens with 1:2.5 ratio can be explained in terms of density because the density of the recycled aggregate was only $4 \%$ lower than that of the natural aggregate. Density values of mortars are influenced by partial replacement of the natural aggregate with the lightweight and recycled aggregates. Density values of mortars with a rich paste volume (1:2.5) are higher than those of mortars with 1:3 ratio as the former contain larger amounts of cement.

Lightweight aggregate mortars due to the physical characteristics of the aggregate, such as high porosity and absorption. Mortars with 1:3 ratio have an entrained air content 50\% higher than mortars with 1:2.5 ratio, which can be attributed to the increase in cement content in the latter. This helps to fill voids and reduce porosity, thus increasing density, which is related to entrained air content. It is also observed that recycled aggregate mortars with 1:3 ratio have a higher entrained air content than natural aggregate mortars, a fact not observed in mortars with 1:2.5 ratio, whose entrained air content was reduced with reducing voids in the mortars. These results are not in line with the findings of VEGAS et al. [4], JIMÉNEZ et al. [23] and LEDESMA et al. [7]. That is relevant because poors compositions (1:10, 1:7 and 1:7, respectively) were used causing no significance contributions on entrained-air content of fresh mortars.

In terms of consistency, the pre-wetting procedure had little influence on the making of mortars with ratio of $1: 3$, while for mortars with ratio of $1: 2.5$, paste consistency increased with the use of pre-wetting aggregates (Table 4). Additionally, mortars with ratio of 1:2.5 had higher consistency, as expected with the decreased aggregate content and increased cement content. Consistency of mortars with ratio of 1:3 decreased considerably when lightweight aggregate was incorporated into the paste and it consumed part of the water of the mixture due to its high absorption capacity, impairing consistency of specimens. The effective w/c ratio was lower than that of the other mortars, even when using pre-wetting lightweight aggregate, due to the great absorption capacity of this material. Natural aggregate mortars had greater consistency for both w/c ratios.

Table 3: Physical properties of mortars. 


\begin{tabular}{|l|c|c|c|}
\hline \multicolumn{1}{|c|}{ Mortars } & $\begin{array}{c}\text { Density } \\
\left(\mathbf{g} / \mathbf{c m}^{\mathbf{3}}\right)\end{array}$ & $\begin{array}{c}\text { Entrained air } \\
(\mathbf{\%})\end{array}$ & $\begin{array}{c}\text { Consistency } \\
(\mathbf{m m})\end{array}$ \\
\hline NA-2.5 & 2.23 & 3.8 & 218.5 \\
\hline LWA-2.5 & 1.89 & 17.1 & 171.0 \\
\hline LWA + PS-2.5 & 1.93 & 15.7 & 178.0 \\
\hline RCA-2.5 & 2.24 & 2.7 & 185.5 \\
\hline RCA + PS-2.5 & 2.23 & 3.3 & 193.0 \\
\hline NA-3 & 2.18 & 7.0 & 140.0 \\
\hline LWA-3 & 1.63 & 29.7 & 108.0 \\
\hline LWA + PS-3 & 1.65 & 28.8 & 108.0 \\
\hline RCA-3 & 2.03 & 13.2 & 125.0 \\
\hline RCA + PS-3 & 2.10 & 10.0 & 123.5 \\
\hline
\end{tabular}

Table 4: Statistical results of the physical properties of mortars

a) DENSITY: Analysis of variance

\begin{tabular}{l|c|l|c|c|c}
\hline $\begin{array}{c}\text { SOURCE OF VARIA- } \\
\text { TION }\end{array}$ & SS & DOF & MS & F & P-VALUE \\
\hline Aggregate & 0.7543 & 4 & 0.1886 & 589.3 & 0.000000 \\
\hline Mix Ratio & 0.1730 & 1 & 0.1730 & 540.6 & 0.000000 \\
\hline Aggreg*Ratio & 0.0365 & 4 & 0.0091 & 28.5 & 0.000019 \\
\hline Residue & 0.0032 & 9 & 0.0003 & \multicolumn{1}{|c}{}
\end{tabular}

Note: SS = Sum of Squares; DOF = Degree of Freedom; MS = Mean Squares

b) DENSITY: Duncan Test

\begin{tabular}{l|l|l|l|l|l|l|l} 
& \multicolumn{6}{c}{ HOMOGENEOUS GROUPS } \\
\hline MORTARS & $\mathbf{1}$ & $\mathbf{2}$ & $\mathbf{3}$ & $\mathbf{4}$ & $\mathbf{5}$ & $\mathbf{6}$ & $\mathbf{7}$ \\
\hline NA-3 & & & $=$ & & & & \\
\hline NA-2.5 & $=$ & & & & & & \\
\hline LWA-3 & & $=$ & & & & & \\
\hline LWA-2.5 & & & & $=$ & & & \\
\hline LWA+PS-3 & & $=$ & & & & & \\
\hline LWA+PS -2.5 & & & & & $=$ & & \\
\hline RCA-3 & & & & & & $=$ & \\
\hline RCA -2.5 & $=$ & & & & & & \\
\hline RCA+PS-3 & & & & & & & $=$ \\
\hline RCA+PS -2.5 & $=$ & & & & & & \\
\hline
\end{tabular}

Note: samples equal to each other have the 'equal' symbol in the same homogeneous group.

c) ENTRAINED AIR CONTENT: Duncan Test

\begin{tabular}{l|l|l|l|l|l|l|l|l|l|l}
\cline { 2 - 9 } & \multicolumn{7}{c}{ HOMOGENEOUS GROUPS } \\
\hline ARGAMASSAS & $\mathbf{1}$ & $\mathbf{2}$ & $\mathbf{3}$ & $\mathbf{4}$ & $\mathbf{5}$ & $\mathbf{6}$ & $\mathbf{7}$ & $\mathbf{8}$ & $\mathbf{9}$ & $\mathbf{1 0}$ \\
\hline NA-3 & $=$ & & & & & & & & & \\
\hline NA-2.5 & & $=$ & & & & & & & & \\
\hline LWA-3 & & & $=$ & & & & & & & \\
\hline LWA-2.5 & & & & $=$ & & & & & & \\
\hline LWA+PS-3 & & & & & $=$ & & & & & \\
\hline LWA+PS -2.5 & & & & & & $=$ & & & & \\
\hline RCA-3 & & & & & & & $=$ & & & \\
\hline RCA -2.5 & & & & & & & & $=$ & & \\
\hline RCA+PS-3 & & & & & & & & & $=$ & \\
\hline RCA+PS -2.5 & & & & & & & & & & $=$ \\
\hline
\end{tabular}

d) CONSISTENCY: Duncan Test

\begin{tabular}{l|l|l|l|l|l|l|l|l}
\cline { 2 - 8 } & \multicolumn{7}{c}{ HOMOGENEOUS GROUPS } \\
\hline MORTARS & $\mathbf{1}$ & $\mathbf{2}$ & $\mathbf{3}$ & $\mathbf{4}$ & $\mathbf{5}$ & $\mathbf{6}$ & $\mathbf{7}$ & $\mathbf{8}$ \\
\hline NA-3 & & & $=$ & & & & & \\
\hline
\end{tabular}




\begin{tabular}{l|l|l|l|l|l|l|l|l}
\hline NA-2.5 & & & & $=$ & & & & \\
\hline LWA-3 & $=$ & & & & & & & \\
\hline LWA-2.5 & & & & & $=$ & & & \\
\hline LWA+PS-3 & $=$ & & & & & & & \\
\hline LWA+PS -2.5 & & & & & & $=$ & & \\
\hline RCA-3 & & $=$ & & & & & & \\
\hline RCA-2.5 & & & & & & & $=$ & \\
\hline RCA+PS-3 & & $=$ & & & & & & \\
\hline RCA+PS -2.5 & & & & & & & & $=$ \\
\hline
\end{tabular}

\subsection{Heat of hydration}

The heat of hydration test results are displayed in Table 5. Based on the value of the area under the curve of the heat of hydration for 1:3 ratio, it can be concluded that the natural aggregate mortar has the highest hydration content $(59.0 \mathrm{~J} / \mathrm{kg})$. On the other hand, lightweight aggregate mortars show smaller values because the effective w/c ratio is lower for the lightweight aggregate; therefore, there is less water available for cement hydration. The pre-wetting procedure in LWA+PS and RCA+PS mortars with ratio 1:3 does not influence the heat generated. However, it affects the initial setting time since these mortars show an initial setting time closer to that of the natural aggregate mortar with 1:3 ratio. For 1:2.5 ratio, dried aggregate (NA, LWA, and $\mathrm{RCA}$ ) mortars show the lowest hydration content, whereas the highest hydration content is observed for prewetted recycled aggregate $(\mathrm{RCA}+\mathrm{PS}=69.2 \mathrm{~J} / \mathrm{kg}$ ) mortars. In other words, pre-wetting prevented the aggregate absorbing water from the mixture. Hence, the water absorbed by the aggregate before the preparation of mortars remained available, i.e. it was released from the interior of the grain to the paste, thus improving cement hydration.

In most mortars with 1:2.5 ratio, the lightweight and recycled aggregates improved hydration, especially in the case of pre-wetted aggregates. That was because the cement was better hydrated by the water available in the porous aggregates. Hence, with the increase of the heat of hydration, these porous aggregates released the water from their interior to the paste. On the other hand, in natural aggregate mortars with the same ratio, the water inside the aggregate pores was not enough to hydrate all the cement. The highest hydration content was found for natural aggregate mortars with 1:3 ratio since the amount of water available was enough to hydrate all the cement.

Table 5: Results of the heat of hydration test

\begin{tabular}{|l|c|c|c|c|c|c|}
\hline \multicolumn{1}{|c|}{ Mortars } & $\begin{array}{c}\text { Initial setting } \\
\text { time (h:min) }\end{array}$ & $\begin{array}{c}\text { Final setting } \\
\text { time (h:min) }\end{array}$ & $\begin{array}{c}\text { Time variation } \\
\text { (h:min) }\end{array}$ & $\begin{array}{c}\text { Max Qi } \\
(\mathbf{J} / \mathbf{k g})\end{array}$ & $\begin{array}{c}\mathbf{Q}_{\text {máx }} \\
(\mathbf{J} / \mathbf{k g})\end{array}$ & $\mathbf{J}$ \\
\hline NA-2.5 & $3: 17$ & $7: 02$ & $3: 45$ & 84.6 & 253.9 & 59.5 \\
\hline LWA-2.5 & $4: 25$ & $8: 53$ & $4: 28$ & 65.8 & 260.3 & 61.0 \\
\hline LWA + PS-2.5 & $4: 18$ & $8: 42$ & $4: 24$ & 71.9 & 246.9 & 62.5 \\
\hline RCA-2.5 & $3: 23$ & $7: 00$ & $3: 37$ & 82.2 & 260.3 & 61.0 \\
\hline RCA + PS-2.5 & $3: 24$ & $7: 18$ & $3: 54$ & 95.6 & 306.3 & 71.8 \\
\hline NA-3 & $4: 12$ & $6: 23$ & $2: 11$ & 78.7 & 253.9 & 59.0 \\
\hline LWA-3 & $6: 20$ & $9: 44$ & $3: 24$ & 46.7 & 158.3 & 40.1 \\
\hline LWA + PS-3 & $5: 42$ & $8: 54$ & $3: 12$ & 47.3 & 155.5 & 39.0 \\
\hline RCA-3 & $3: 23$ & $6: 23$ & $3: 00$ & 75.9 & 205.1 & 46.4 \\
\hline RCA + PS-3 & $3: 53$ & $6: 03$ & $2: 10$ & 65.1 & 198.6 & 45.2 \\
\hline
\end{tabular}

Note: Max Qi = Maximum heat generated; $\int=$ integral; $\mathrm{Q}_{\operatorname{máx}}=$ Total heat amount generated.

The heat curve generated over time for mortars is plotted in Figure 1, where the first peak represents hydration of $\mathrm{C}_{3} \mathrm{~A}$, followed by a dormant period due to the interaction between $\mathrm{CaSO}_{4}$ and $\mathrm{C}_{3} \mathrm{~A}$. Finally, the peak of acceleration occurs during hydration of $\mathrm{C}_{3} \mathrm{~S}$ and $\mathrm{C}_{2} \mathrm{~S}$, leading to the formation of hydrated calcium silicate and hydroxide of calcium. Natural aggregate mortars with 1:2.5 ratio and recycled aggregate (RCA and RCA+PS) mortars required almost the same amount of initial setting time. However, for 1:3 ratio, recycled aggregate mortars accelerated the initial setting time. Moreover, for both ratios, lightweight aggregate mortars not only delayed the initial setting time but also reduced the heat of hydration. This delay in hydration can be explained by the presence of sulfates in the aggregates (specifically, the sulfate in the lightweight aggregate was in a more soluble form despite being at a lower concentration than the sulfate in the recycled aggregate). The presence of sulfate and lower cement consumption contributed to reducing the heat of hydra- 
tion. It can be seen that mortars with 1:2.5 ratio show a higher heat of hydration because of a higher amount of cement. The difference between natural and recycled aggregate mortars is not pronounced.

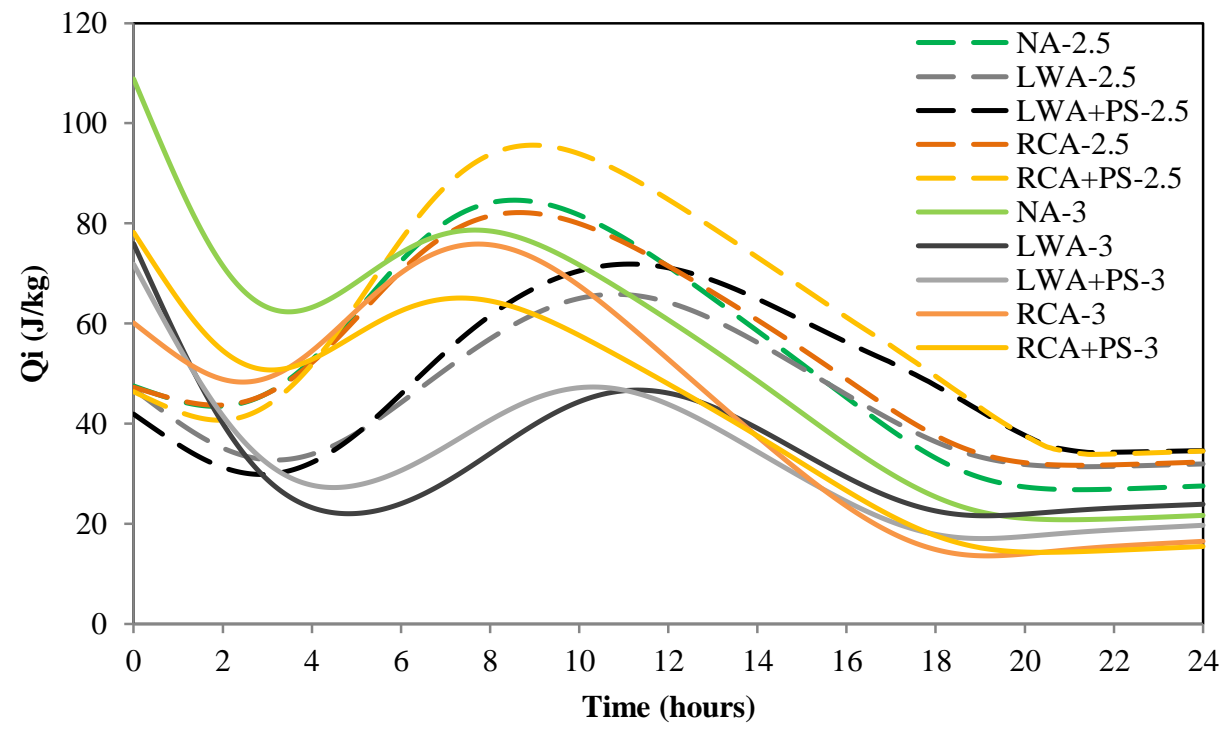

Figure 1: Amount of heat generated over time in mortars.

\subsection{Physical properties of hardened mortars}

Density values of mortars in the hardened state at 28 days are shown in Figure 2. The results of the analysis of variance ( $p$-value (0.00) of the F-test was lower than 0.05) and Duncan test at a 95\% confidence level show the impact of partial replacement of the natural aggregate with the lightweight aggregate (Table 6). Natural aggregate and recycled aggregate mortars are statistically the same, regardless of the ratio. These results do not agree with those observed by VEGAS et al. [4], NENO et al. [24] and LEDESMA et al. [7].

The reduction values obtained by these authors compared to the values in Figure 2 can be explained by the density of the aggregates. In the present study, these values are similar (reduction of $4 \%$ for the recycled aggregate) to those found by VEGAS et al. [4], NENO et al. [24] and LEDESMA et al. [7], i.e. 20\%, 25\% and $16 \%$, respectively, for the recycled aggregate, values significantly lower than those of the natural aggregate. The increased water content was also reported by the above authors.

Recycled, and especially, lightweight aggregate mortars with 1:2.5 ratio show increased density whereas the density of pre-wetting aggregate mortars with 1:3 ratio was lower (Figure 2).

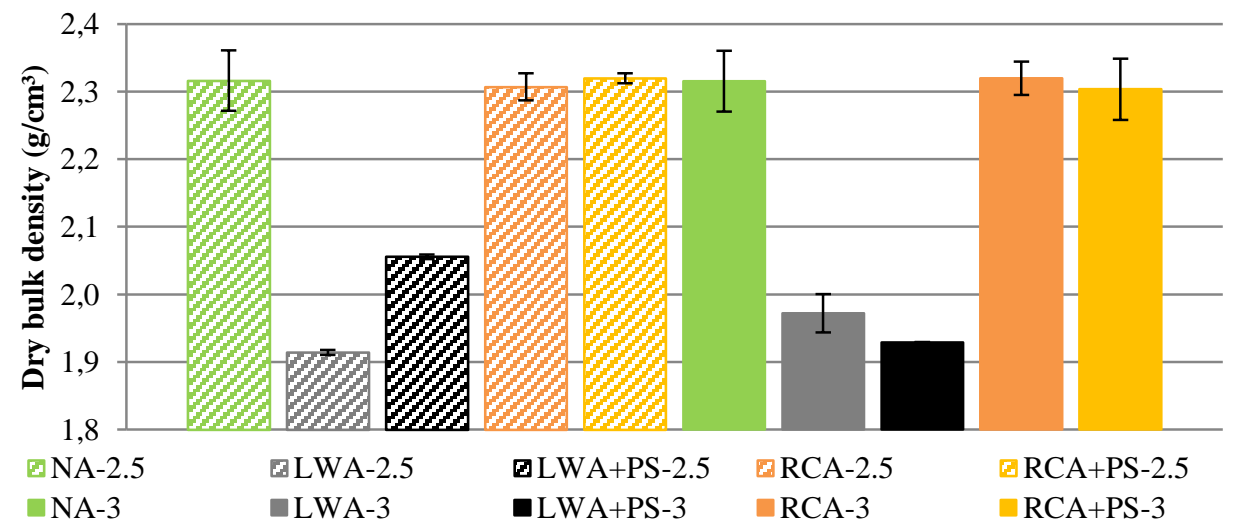

Figure 2: Density of hardened mortars at 28 days. 
Table 6: Statistical results: a) Analysis of Variance (ANOVA) and b) Duncan Test (summary table) for density values.

a) Analysis of variance

\begin{tabular}{l|c|c|c|c|c}
\hline $\begin{array}{c}\text { SOURCE OF VARIA- } \\
\text { TION }\end{array}$ & SS & DOF & MS & F & P-VALUE \\
\hline Aggregate & 0.5859 & 4 & 0.1465 & 56.33 & 0.000001 \\
\hline Mix Ratio & 0.0013 & 1 & 0.0013 & 0.49 & 0.498903 \\
\hline Aggreg*Ratio & 0.0197 & 4 & 0.0049 & 1.90 & 0.187740 \\
\hline Residue & 0.0260 & 9 & 0.0026 & \multicolumn{1}{c}{}
\end{tabular}

b) Duncan Test

\begin{tabular}{l|c|c|c}
\multicolumn{1}{c}{} & \multicolumn{3}{c}{ b) Duncan Test } \\
\cline { 2 - 4 } \multicolumn{1}{c}{ MORTARS } & $\mathbf{1}$ & $\mathbf{2}$ & $\mathbf{3}$ \\
\hline NA-3 & $=$ & & \\
\hline NA-2.5 & $=$ & & \\
\hline LWA-3 & & $=$ & $=$ \\
\hline LWA-2.5 & & $=$ & \\
\hline LWA+PS-3 & & $=$ & \\
\hline LWA+PS -2.5 & & & $=$ \\
\hline RCA-3 & $=$ & & \\
\hline RCA -2.5 & $=$ & & \\
\hline RCA+PS-3 & $=$ & & \\
\hline RCA+PS -2.5 & $=$ & & \\
\hline
\end{tabular}

\subsection{Mechanical strength}

The results of flexural strength over time with their respective standard deviation are summarized in Figure 3. Table 8 shows the statistical analysis data. As can be noted, the analysis of variance (p-value of the F-test is lower than 0.05) indicates a significant difference between the averages regarding the aggregate used and the pre-wetting procedure. In turn, the ratio does not influence the results considerably (p-value of the F-test is higher than 0.05). The Duncan tests allowed homogeneous groups, i.e. samples statistically equal, to be identified. Thus, 4, 3 and 5 equality groups at 3, 28 and 90 days were determined, respectively. Flexural strength of reference mortar with the two ratios has values similar to those at 28 days when compared to recycled aggregate mortars. These values are in agreement with those observed by CORINALDESI and MORICONI [3] for mortars with $1: 3 \mathrm{w} / \mathrm{c}$ ratio of 0.71 and total replacement of natural aggregate with recycled concrete aggregate. These authors concluded that the sharp-cornered shape of concrete particles contributes to improving bond strength at the interface between aggregate and surrounding cement paste.

Improvement in flexural strength and/or the comparable strengths of recycled or lightweight aggregate mortars in relation to NA samples resulted from improvement in the ITZ due to the penetration of cement hydration products into the pores of the porous aggregates, the former acting as mechanical interlacing. This observation is consistent with the results reported by VARGAS et al. [25]. This beneficial effect was attributed to the presence of cement mortar attached to the recycled aggregate, which promoted a better connection between the recycled aggregate and the new cement paste. Moreover, the rough surface of the recycled aggregate improved the ITZ microstructure and flexural strength [26, 27]. This comparable strength of mortars was also attributed to the effective w/c ratio, which was lower than that of recycled aggregate mortars. The heat of hydration test showed that lightweight aggregate mortars had a smaller hydration content and, consequently, less strength for their lower effective w/c ratio.

Mortars whose aggregate had not been pre-wetting exhibited better adhesion of the paste to the aggregate. This may be due to the initial water absorption of the paste in its fresh state, which may account for the improved properties of mortars after 3 days without pre-wetting. Increasing the age (28 and 90 days) equalized this effect thanks to the water absorbed inside the aggregate and the lower total w/c ratio of the paste.

As can be observed, the strength of pre-wetting specimens aged for 3, 28 and 90 days for both ratios tended to increase when compared to non-wetted specimens, whose strength did not vary significantly from 3 to 90 days. Lightweight aggregate mortars had lower strength at all ages, a fact associated with the porosity 
of the aggregate. According to BOGAS et al. [28], the decline in strength was decided determined by the decline in strength of the porous materials.

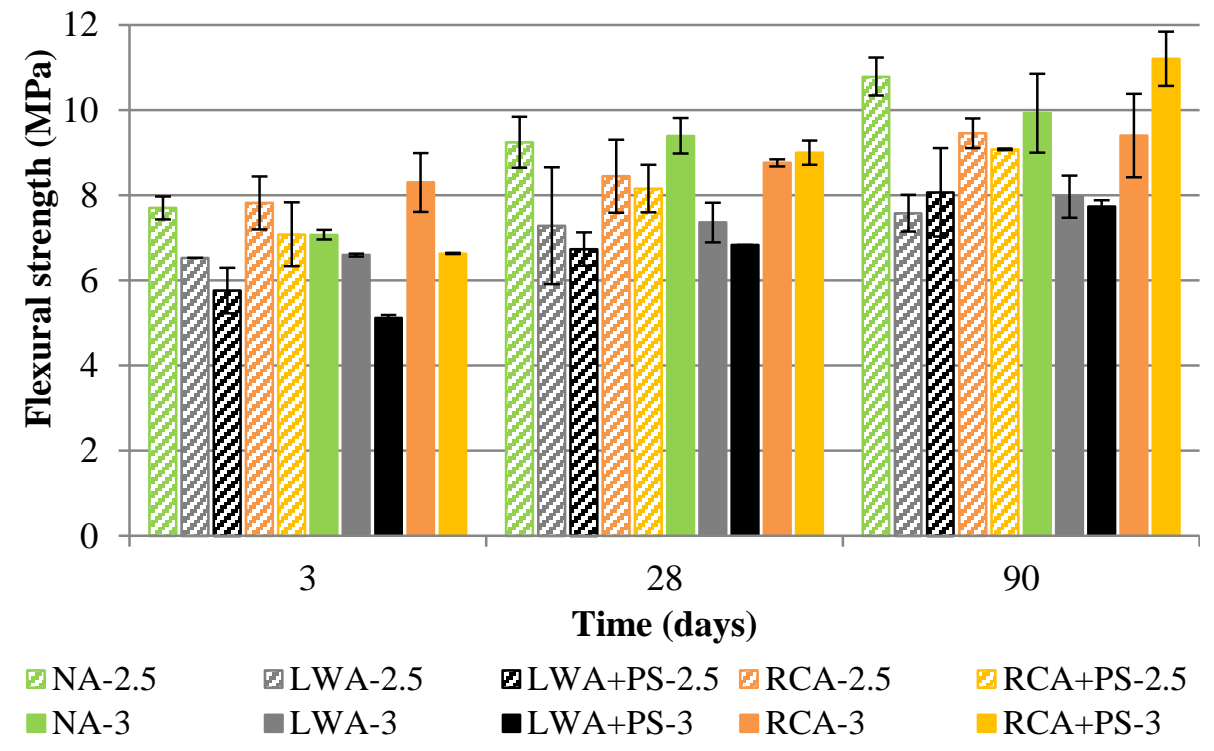

Figure 3: Flexural strength of mortars.

The rate of increase in flexural strength is set forth in Table 7 . The 3 to 28 days and 28 to 90 days increase of mortars with ratio of 1:3 was greater when using the pre-wetted aggregate, because, with the use of porous aggregate, water availability after mixing helped to improve the ITZ, making it denser, less porous and less permeable. This finding is in line with other previous studies [29, 30,9] and was also observed in mortars with ratio of 1:2.5, except for the natural aggregate mortar, which had a larger increase in strength than the other mixtures. Despite this, natural aggregate (NA) and recycled aggregate (RCA and RCA+PS) mortars exhibited similar strengths at all ages.

Table 7: Rate of increase in flexural strength of mortars.

\begin{tabular}{l|c|c}
\cline { 2 - 3 } \multicolumn{1}{c|}{} & \multicolumn{2}{c}{ INCREASE IN FLEXURAL STRENGTH (\%) } \\
\hline MORTARS & 3 TO 28 DAYS & 28 TO 90 DAYS \\
\hline NA-3 & 20.1 & 16.7 \\
\hline NA-2.5 & 11.5 & 4.1 \\
\hline LWA-3 & 16.9 & 19.8 \\
\hline LWA-2.5 & 8.0 & 12.0 \\
\hline LWA+PS-3 & 15.2 & 11.3 \\
\hline LWA+PS -2.5 & 32.9 & 5.6 \\
\hline RCA-3 & 11.6 & 8.2 \\
\hline RCA -2.5 & 33.4 & 13.3 \\
\hline RCA+PS-3 & 5.5 & 7.3 \\
\hline RCA+PS -2.5 & 35.8 & 24.4 \\
\hline
\end{tabular}

Table 8: Statistical analyses of flexural strength of mortars at 3, 28 and 90 days.

a) 3 DAYS: Duncan Test

\begin{tabular}{|c|c|c|c|c|}
\hline & \multicolumn{4}{|c|}{ HOMOGENEOUS GROUPS } \\
\hline MORTARS & 1 & 2 & 3 & 4 \\
\hline NA-3 & $=$ & $=$ & & \\
\hline NA-2.5 & & $=$ & $=$ & \\
\hline LWA-3 & $=$ & & & \\
\hline LWA-2.5 & $=$ & & & \\
\hline LWA+PS-3 & & & & $=$ \\
\hline LWA+PS -2.5 & $=$ & & & \\
\hline RCA-3 & & & $=$ & \\
\hline
\end{tabular}




\begin{tabular}{l|l|l|l|l}
\hline RCA -2.5 & & $=$ & $=$ & \\
\hline RCA+PS-3 & $=$ & & & \\
\hline RCA+PS -2.5 & $=$ & $=$ & & \\
\hline
\end{tabular}

b) 28 DAYS: Duncan Test

\begin{tabular}{l|c|c|c}
\cline { 2 - 4 } \multicolumn{1}{c|}{} & \multicolumn{3}{c}{ HOMOGENEOUS GROUPS } \\
\hline MORTARS & $\mathbf{1}$ & $\mathbf{2}$ & $\mathbf{3}$ \\
\hline NA-3 & $=$ & & \\
\hline NA-2.5 & $=$ & & \\
\hline LWA-3 & & $=$ & $=$ \\
\hline LWA-2.5 & & $=$ & $=$ \\
\hline LWA+PS-3 & & $=$ & \\
\hline LWA+PS -2.5 & & $=$ & \\
\hline RCA-3 & $=$ & & $=$ \\
\hline RCA -2.5 & $=$ & & $=$ \\
\hline RCA+PS-3 & $=$ & & \\
\hline RCA+PS -2.5 & $=$ & $=$ & $=$ \\
\hline
\end{tabular}

c) 90 DAYS: Duncan Test

\begin{tabular}{l|c|c|c|c|c}
\multicolumn{1}{c|}{} & \multicolumn{5}{c}{ HOMOGENEOUS GROUPS } \\
\hline MORTARS & $\mathbf{1}$ & $\mathbf{2}$ & $\mathbf{3}$ & $\mathbf{4}$ & $\mathbf{5}$ \\
\hline NA-3 & & & $=$ & $=$ & $=$ \\
\hline NA-2.5 & & & & $=$ & $=$ \\
\hline LWA-3 & $=$ & $=$ & & & \\
\hline LWA-2.5 & $=$ & & & & \\
\hline LWA+PS-3 & $=$ & & & & \\
\hline LWA+PS -2.5 & $=$ & $=$ & & & \\
\hline RCA-3 & & $=$ & $=$ & $=$ & \\
\hline RCA -2.5 & & $=$ & $=$ & $=$ & \\
\hline RCA+PS-3 & & & & & $=$ \\
\hline RCA+PS -2.5 & $=$ & $=$ & $=$ & & \\
\hline
\end{tabular}

The compressive strength test results are summarized in Figure 4 . It can be said at $95 \%$ confidence level ( $p$-value of the $F$-test was lower than 0.05 ) that aggregate partial replacement, the pre-wetting procedure, and the ratio used affected these results considerably. However, the interaction between aggregate and ratio was not significant at 90 days, according to the analysis of variance ( $p$-value $(0.20)$ of the $F$-test was higher than 0.05) (Table 10). The Duncan tests allowed which samples were statistically equal at each of the 3 ages to be determined. Strength of pre-wetted recycled aggregate mortars improved slightly at all ages. This may be due to the water content of the aggregate, which contributes to better hydration of the paste around the aggregate particles in the long term. Such improvement was not observed for lightweight aggregate mortars with ratio of $1: 3$ at 3 and 28 days (LWA+PS). BOGAS et al. [28] stated that this improvement is due to the high porosity of aggregates, so the interface transition zone is improved and compressive strength is essentially affected by aggregate strength. This improvement in compressive strength of pre-wetted recycled aggregate mortars was also observed in $100 \%$ recycled aggregate mortars by JOCHEM et al. [31].

The natural aggregate mortar and recycled aggregate mortars had similar compressive strength values for both ratios, which can be attributed to the refinement of the ITZ microstructure and anchoring of the cement paste with to the porous aggregate. These results are in accordance with the findings of VEGAS et al. [4], who concluded that up to $25 \%$ of natural aggregate can be replaced by recycled concrete aggregate (by mass) without loss of mechanical strength in masonry mortars. However, the opposite was found by CORINALDESI and MORICONI [3], who observed a 32\% and 22\% strength reduction in recycled concrete aggregate mortars at 7 and 28 days, respectively. They concluded that this was due to lower density and higher water absorption of recycled aggregate fractions compared to quartz aggregate fractions. However, for mortars with a $16 \%$ replacement of natural aggregate with lightweight aggregate (with a 1:1.95 w/c ratio of 0.3 ), ZOU et al. [8] obtained a strength reduction of $16 \%$ and $10 \%$ compared to the reference mortar at 7 and 28 days, respectively. DAPENA et al. [5] tested six replacement levels (0, 5, 10, 15, 20 and 50\%) of two types of natural aggregates (silicon and limestone) with recycled aggregate using a 1:3 ratio (by mass). The results indicated that the use of up to $20 \%$ of recycled aggregate reduced compressive and flexural strength levels whereas with $50 \%$ of replacement no strength was developed. 
The loss in mechanical strength of lightweight aggregate mortars was due to a lower effective w/c ratio, resulting in less water available in the system to hydrate the cement. According to the findings by BOGAS et al. [28] and VARGAS et al. [25], the increase in compressive strength of lightweight aggregate mortars was limited by the strength of the aggregate. It should be noted that failure of lightweight aggregate mortars occurred earlier in the aggregates than in the paste. According to BENTUR et al. [32] and ZOU and WEISS [10], the strength reduction of mortars internally cured at early ages ( 7 days or earlier) is due to the porosity of the lightweight aggregate, in agreement with the results found in the present study.

Strength of recycled aggregate mortars was higher than that of lightweight aggregate mortars at all tested ages for a number of reasons, i.e. larger specific area; lower void ratio; amount of anhydrous cement present in the recycled aggregate completing its hydraulic reaction in contact with water; higher strength of the recycled aggregate; and cement particles adhered to the recycled aggregate promoting better interfacial bonding between the aggregate and the cement paste [3, 24].

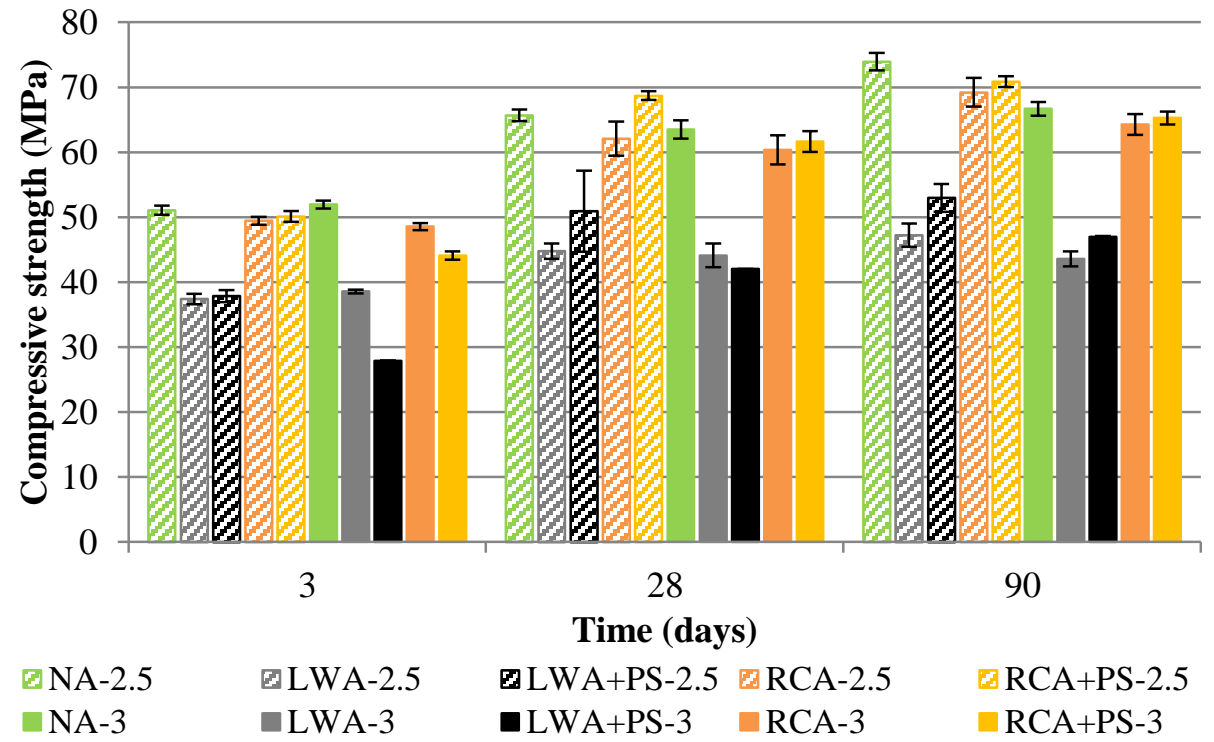

Figure 4: Compressive strength of mortars.

The rate of increase in compressive strength from days 3 to 28 and from days 28 to 90 is shown in Table 9. It can be seen that from days 3 to 28 and for both ratios the increase of strength was more substantial when using the pre-wetted aggregate. This fact was not observed from days 28 to 90 , as the pre-wetted aggregates used did not absorb water from the mixture. Thus, addition of the pre-wetted aggregate increased the hydration content of the cement paste, which absorbed excessive water to complete its hydration. This contributed to this strength increase in such a way that pre-wetted aggregate mortars practically reached their maximum strength at 28 days. Additionally, at 28 and 90 days, these mortars obtained higher strength than the reference mortar without pre-wetting (LWA and RCA).

Table 9: Rate of increase in compressive strength of mortars.

\begin{tabular}{l|c|c}
\cline { 2 - 3 } \multicolumn{1}{c|}{} & \multicolumn{2}{|c}{ INCREASE IN COMPRESSIVE STRENGTH (\%) } \\
\hline MORTARS & 3 TO 28 DAYS & 28 TO 90 DAYS \\
\hline NA-3 & 28.6 & 12.6 \\
\hline NA-2.5 & 19.7 & 5.5 \\
\hline LWA-3 & 34.5 & 4.0 \\
\hline LWA-2.5 & 25.6 & 11.5 \\
\hline LWA+PS-3 & 37.1 & 3.1 \\
\hline LWA+PS -2.5 & 22.2 & 5.0 \\
\hline RCA-3 & 10.5 & 4.2 \\
\hline RCA -2.5 & 50.9 & 11.7 \\
\hline RCA+PS-3 & 24.3 & 6.4 \\
\hline RCA+PS -2.5 & 39.8 & 5.9 \\
\hline
\end{tabular}


Table 10: Statistical analyses of compressive strength of mortars at 3, 28 and 90 days.

a) 3 DAYS: Duncan Test

\begin{tabular}{l|c|c|c|c|c}
\cline { 2 - 6 } \multicolumn{1}{c|}{} & \multicolumn{6}{c}{ HOMOGENEOUS GROUPS } \\
\hline MORTARS & $\mathbf{1}$ & $\mathbf{2}$ & $\mathbf{3}$ & $\mathbf{4}$ & $\mathbf{5}$ \\
\hline NA-3 & $=$ & & $=$ & & \\
\hline NA-2.5 & & & $=$ & & \\
\hline LWA-3 & & $=$ & & & \\
\hline LWA-2.5 & & $=$ & & & \\
\hline LWA+PS-3 & & & & $=$ & \\
\hline LWA+PS -2.5 & & $=$ & & & \\
\hline RCA-3 & $=$ & & & & \\
\hline RCA -2.5 & $=$ & & & & \\
\hline RCA+PS-3 & & & & & $=$ \\
\hline RCA+PS -2.5 & $=$ & & & & \\
\hline
\end{tabular}

b) 28 DAYS: Duncan Test

\begin{tabular}{l|c|c|c|c|c|c|c}
\cline { 2 - 8 } & \multicolumn{7}{c}{ HOMOGENEOUS GROUPS } \\
\hline MORTARS & $\mathbf{1}$ & $\mathbf{2}$ & $\mathbf{3}$ & $\mathbf{4}$ & $\mathbf{5}$ & $\mathbf{6}$ & $\mathbf{7}$ \\
\hline NA-3 & & $=$ & & & $=$ & & \\
\hline NA-2.5 & & & & & $=$ & & \\
\hline LWA-3 & & & $=$ & $=$ & & & \\
\hline LWA-2.5 & & & & $=$ & & $=$ & \\
\hline LWA+PS-3 & & & $=$ & & & & \\
\hline LWA+PS -2.5 & & & & & & & \\
\hline RCA-3 & $=$ & & & & & & \\
\hline RCA-2.5 & $=$ & $=$ & & & & & \\
\hline RCA+PS-3 & $=$ & $=$ & & & & & \\
\hline RCA+PS -2.5 & & & & & & & $=$ \\
\hline
\end{tabular}

c) 90 DAYS: Duncan Test HOMOGENEOUS GROUPS

\begin{tabular}{l|c|c|c|c|c}
\hline MORTARS & $\mathbf{1}$ & $\mathbf{2}$ & $\mathbf{3}$ & $\mathbf{4}$ & $\mathbf{5}$ \\
\hline NA-3 & & $=$ & $=$ & & \\
\hline NA-2.5 & & & & & $=$ \\
\hline LWA-3 & $=$ & & & & \\
\hline LWA-2.5 & $=$ & & & & \\
\hline LWA+PS-3 & $=$ & & & & \\
\hline LWA+PS -2.5 & & & & $=$ & \\
\hline RCA-3 & & $=$ & & & \\
\hline RCA -2.5 & & & $=$ & & \\
\hline RCA+PS-3 & & $=$ & & & \\
\hline RCA+PS -2.5 & & & $=$ & & \\
\hline
\end{tabular}

\subsection{Dimensional instability}

Expansion and shrinkage of mortars were analyzed according to standard NBR 15261 [20]. Based on test data, trend lines were added, and the curve equation and $\mathrm{R}^{2}$ were generated, as shown in Table 11 . The equations allowed expansion/shrinkage values to be estimated for ages 1, 3, 7, 28 and 120 days. Figure 5 displays dimensional instability of specimens generated with the aid of the curve equation.

It is worth noting that recycled and natural aggregate mortars shrank (negative values) while lightweight aggregate mortars had a tendency to expand (positive values). This may have been due to the presence of sulfate in the lightweight aggregate, which forms ettringite and, consequently, expands. These findings are 
in line with the results reported by ZOU et al. [8], who studied the shrinkage of mortars with a $16 \%$ replacement of natural aggregate with lightweight aggregate or normal weight porous aggregate. ZOU et al. observed that these mortars expanded whereas the natural aggregate mortar shrank.

Mortars with larger amounts of cement paste showed greater retraction. This behavior was observed in mortars NA-2.5 and NA-3 and non-wetted recycled aggregate mortars, although the latter showed smaller retraction because of their higher aggregate content.

Dimensional instability of all mortars increased with curing time up to 10 days. Dry shrinkage of recycled aggregate mortars, RCA and RCA+PS with 1:3 ratio and RCA with 1: 2.5 ratio, was lower than that of their respective references (NA-3 and NA-2.5), i.e. water availability of the recycled aggregate led to better hydration and, consequently, a shrinkage reduction. DUAN and POON [27] and LEDESMA et al. [7] also observed this shrinkage reduction in concrete with recycled concrete aggregate. However, other studies have found that shrinkage increased in recycled aggregate mortars [6, 28]. This was observed in pre-wetted recycled aggregate mortars with 1:2.5 ratio (RCA+PS), which was the mortars with the highest heat of hydration.

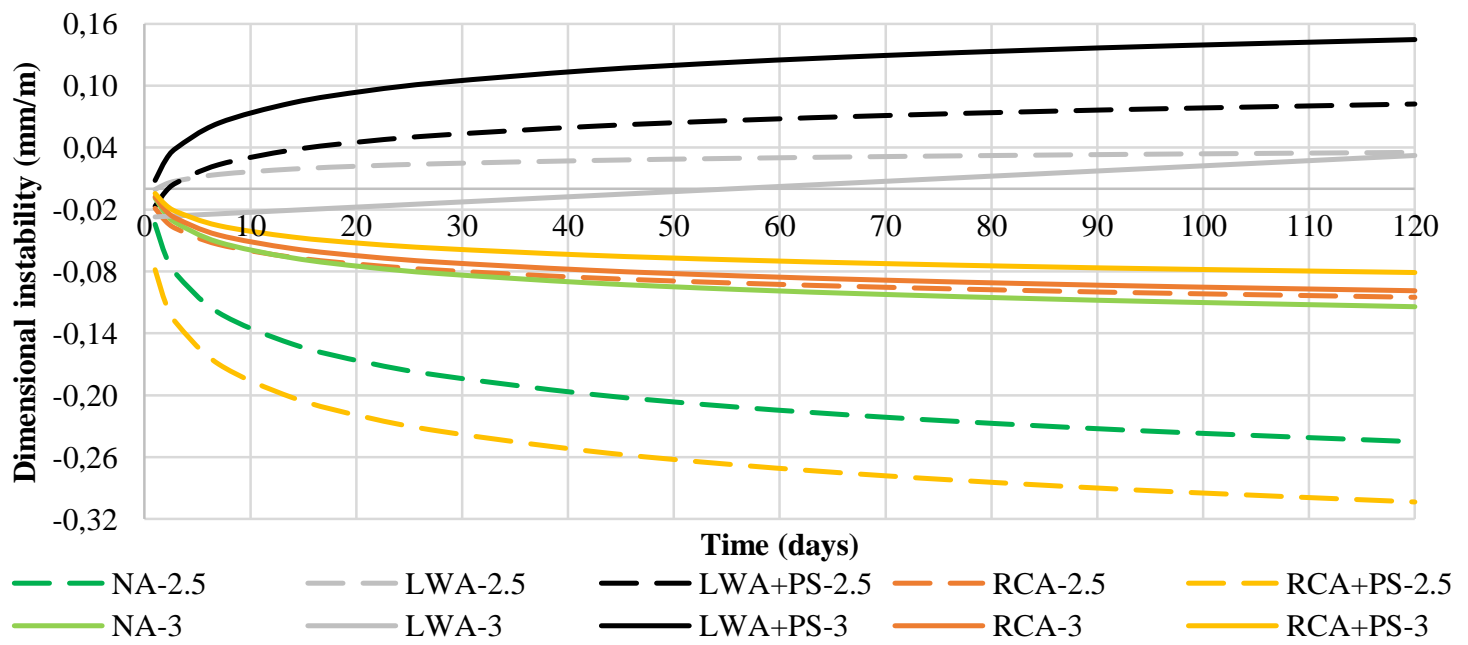

Figure 5: Dimensional instability of mortars over time.

Table 11: Curve equation, $\mathrm{r}^{2}$ and dimensional instability of mortars at different ages.

\begin{tabular}{|l|c|c|c|c|c|c|c|}
\hline \multirow{2}{*}{ Mortars } & \multirow{2}{*}{$\mathbf{R}^{\mathbf{2}}$} & \multirow{2}{*}{ Curve equation } & \multicolumn{4}{c|}{ Dimensional instability $(\mathbf{m m} / \mathbf{m})$} \\
\cline { 4 - 8 } & & & $\mathbf{1}$ & $\mathbf{3}$ & $\mathbf{7}$ & $\mathbf{2 8}$ & $\mathbf{1 2 0}$ \\
\hline NA-2.5 & 0.9009 & $\mathrm{y}=-0.044 \ln (\mathrm{x})-0.0344$ & -0.034 & -0.083 & -0.120 & -0.181 & -0.245 \\
\hline LWA-2.5 & 0.5347 & $\mathrm{y}=0.0075 \ln (\mathrm{x})-0.0006$ & -0.001 & 0.008 & 0.014 & 0.024 & 0.035 \\
\hline LWA + PS-2.5 & 0.8106 & $\mathrm{y}=0.0207 \ln (\mathrm{x})-0.0169$ & -0.017 & 0.006 & 0.023 & 0.052 & 0.082 \\
\hline RCA-2.5 & 0.6152 & $\mathrm{y}=-0.018 \ln (\mathrm{x})-0.0189$ & -0.019 & -0.039 & -0.054 & -0.079 & -0.105 \\
\hline RCA + PS-2.5 & 0.7661 & $\mathrm{y}=-0.047 \ln (\mathrm{x})-0.0784$ & -0.078 & -0.130 & -0.170 & -0.235 & -0.303 \\
\hline NA-3 & 0.8008 & $\mathrm{y}=-0.022 \ln (\mathrm{x})-0.0089$ & -0.009 & -0.033 & -0.052 & -0.082 & -0.114 \\
\hline LWA-3 & 0.6002 & $\mathrm{y}=0.0005 \mathrm{x}-0.0277$ & -0.027 & -0.026 & -0.024 & -0.014 & 0.032 \\
\hline LWA + PS-3 & 0.9553 & $\mathrm{y}=0.0285 \ln (\mathrm{x})+0.0082$ & 0.008 & 0.040 & 0.064 & 0.103 & 0.145 \\
\hline RCA-3 & 0.8307 & $\mathrm{y}=-0.019 \ln (\mathrm{x})-0.0078$ & -0.008 & -0.029 & -0.045 & -0.071 & -0.099 \\
\hline RCA + PS-3 & 0.7268 & $\mathrm{y}=-0.016 \ln (\mathrm{x})-0.0045$ & -0.005 & -0.022 & -0.036 & -0.058 & -0.081 \\
\hline
\end{tabular}

\section{CONCLUSIONS}

Partial (25\%) replacement of natural aggregate with recycled aggregate is a viable alternative considering improvements in the properties of mortars brought about by the absorption capacity of the porous aggregate, which helped to advance cement paste hydration around the aggregates. In addition, the reduction of porosity and permeability in the interfacial transition zone increased the mechanical strength of the material. The use of recycled aggregate can also reduce the heat of hydration and shrinkage over natural aggregate mortars. However, among all studied properties, mortar consistency deserves special attention, since a reduction of up to $15 \%$ was found. 
On the other hand, replacing natural aggregate with lightweight expanded clay aggregate affected negatively the properties of mortars due to higher porosity and lower mechanical strength of this aggregates, as well as their chemical characteristics, since the sulfate content can drastically influence results, for instance by delaying hydration and expansion. Consistency and flexural strength were likewise affected, with a reduction of up to $23 \%$ and $28 \%$ (regardless of ratio (1: 2.5 or $1: 3)$ ), respectively, compared to natural aggregates. Similarly, compressive strength was reduced $32 \%$ with ratio of $1: 2.5$ and $34 \%$ with ratio of $1: 3$, i.e. addition of more cement did not lead to increased strength.

In general, changing the mix ratio from 1:3 to 1:2.5 did not alter the properties of mortars significantly, and 1:3 ratio could be used to reduce cement consumption without significant loss of mechanical strength of the final material. It was also observed that pre-wetting the aggregates had little impact on the properties analyzed.

The results of this study contribute to increasing the recycling rates of fine fraction of recycled aggregates, using them in mortars without detriment to their final properties.

\section{ACKNOWLEDGEMENTS}

The authors are grateful for the financial support from by the Coordination for the Improvement of Higher Education Personnel - CAPES (Process No. 99999.000253/2015-04).

\section{BIBLIOGRAPHY}

[1] ANGULO, S. C., ULSEN, C., JOHN, V. M., et al., "Chemical-mineralogical characterization of C\&D waste recycled aggregates from São Paulo - Brazil”, Waste Management, v. 29, n. 2, pp. 721-730, 2009.

[2] CACHIM, P. B., "Mechanical properties of brick aggregate concrete", Construction and Building Materials, v. 23, n. 3, pp. 1292-1297, 2009.

[3] CORINALDESI, V., MORICONI, G., "Behaviour of cementitious mortars containing different kinds of recycled aggregate", Construction and Building Materials, v. 23, n. 1, pp. 289-294, 2009.

[4] VEGAS, I., AZKARATE, I., JUARRERO, A., et al., "Design and performance of masonry mortars made with recycled concrete aggregates", Materiales de Construcción, v. 59, n. 295, pp. 5-18, 2009.

[5] DAPENA, E., ALAEJOS, P., LOBET, A., et al., "Effect of recycled sand content on characteristics of mortars and concretes", Journal of Materials in Civil Engineering, v. 23, n. 4, pp. 414-422, 2011.

[6] BRAGA, M., BRITO, J., VEIGA, R., "Incorporation of fine concrete aggregates in mortars", Construction and Building Materials, v. 36, pp. 960-968, 2012.

[7] LEDESMA, E. F., JIMÉNEZ, J. R., FERNÁNDEZ, J. M., et al., "Properties of masonry mortars manufactured with fine recycled concrete", Construction and Building Materials, v. 71, pp. 289-298, 2014.

[8] ZOU, D., ZHANG, H., WANG, Y., et al., "Internal curing of mortar with low water to cementitious materials ratio using a normal weight porous aggregate", Construction and Building Materials, v. 96, pp. 209216, 2015.

[9] SIDOROVA, A., VÁZQUEZ-RAMONICH, E., BARRA-BIZINOTTO, M., et al., "Study of the recycled aggregates nature's influence on the aggregate-cement paste interface and ITZ", Construction and Building Materials, v. 68, pp. 677-684, 2014.

[10] ZOU, D., WEISS, J., "Early age cracking behavior of internally cured mortar restrained by dual rings with different thickness", Construction and Building Materials, v. 66, pp. 146-153, 2014.

[11] CUENCA-MOYANO, G. M., MARTÍN-MORALES, M., VALVERDE-PALACIOS, I., et al., "Influence of pre-soaked recycled fine aggregate on the properties of masonry mortar", Construction and Building Materials, v. 70, pp. 71-79, 2014.

[12] ASSOCIAÇÃO BRASILEIRA DE NORMAS TÉCNICAS (2016), NBR 16541: Argamassa para assentamento e revestimento de paredes e tetos - Preparo da mistura para a realização de ensaios. Rio de Janeiro, ABNT - Associação Brasileira de Normas Técnicas.

[13] ASOCIACIÓN ESPAÑOLA DE NORMALIZACIÓN Y CERTIFICACIÓN (2001), UNE-EN 1097-6: Ensayos para determinar las propiedades mecánicas y físicas de los áridos. Parte 6: Determinación de la densidad de partículas y la absorción de agua. Madrid, Asociación Española de Normalización y Certificación.

[14] ASSOCIAÇÃO BRASILEIRA DE NORMAS TÉCNICAS (2006), NBR NM 45: Agregados - Determinação de massa unitária e do volume de vazios. Norma Mercosul. Rio de Janeiro, ABNT - Associação Brasileira de Normas Técnicas. 
[15] ASSOCIAÇÃO BRASILEIRA DE NORMAS TÉCNICAS (2005), NBR 13278: Argamassa para assentamento e revestimento de paredes e tetos - Determinação da densidade de massa e do teor de ar incorporado. Rio de Janeiro, ABNT - Associação Brasileira de Normas Técnicas.

[16] ASSOCIAÇÃO BRASILEIRA DE NORMAS TÉCNICAS (2016), NBR 13276: Argamassa para assentamento e revestimento de paredes e tetos - Determinação do índice de consistência. Rio de Janeiro, ABNT Associação Brasileira de Normas Técnicas.

[17] ASOCIACIÓN ESPAÑOLA DE NORMALIZACIÓN Y CERTIFICACIÓN (2011), UNE-EN 196-9: Métodos de ensayo de cementos. Parte 9: Determinación del calor de hidratación. Método semiadiabático. Madrid, Asociación Española de Normalización y Certificación.

[18] ASSOCIAÇÃO BRASILEIRA DE NORMAS TÉCNICAS (2005), NBR 13280: Argamassa para assentamento e revestimento de paredes e tetos - Determinação da densidade de massa aparente no estado endurecido. Rio de Janeiro, ABNT - Associação Brasileira de Normas Técnicas.

[19] ASOCIACIÓN ESPAÑOLA DE NORMALIZACIÓN Y CERTIFICACIÓN (2005), UNE-EN 196-1: Métodos de ensayo de cementos. Parte 1: Determinación de resistencias mecánicas. Madrid, Asociación Española de Normalización y Certificación.

[20] ASSOCIAÇÃO BRASILEIRA DE NORMAS TÉCNICAS (2005), NBR 15261: Argamassas para assentamento e revestimento de paredes e tetos - Determinação da variação dimensional (retração ou expansão linear). Rio de Janeiro, ABNT - Associação Brasileira de Normas Técnicas.

[21] ASSOCIAÇÃO BRASILEIRA DE NORMAS TÉCNICAS (2004), NBR 15116: Agregados reciclados de resíduos sólidos da construção civil - Utilização em pavimentação e preparo de concreto sem função estrutural - Requisitos. Rio de Janeiro, ABNT - Associação Brasileira de Normas Técnicas.

[22] PEDRO, D., BRITO, J., EVANGELISTA, L., "Influence of the use of recycled concrete aggregates from different sources on structural concrete", Construction and Building Materials, v. 71, pp. 141-151, 2014.

[23] JIMÉNEZ, J. R., AYUSO, J., LÓPEZ, M., FERNÁNDEZ, J. M., et al., "Use of fine recycled aggregates from ceramic waste in masonry mortar manufacturing", Constructions and Building Materials, v. 40, pp. 679-690, 2013.

[24] NENO, C., BRITO, J., VEIGA, R., "Using fine recycled concrete aggregate for mortar production", Materials Research, v. 17, n. 1, pp.168-177, 2014.

[25] VARGAS, P., RESTREPO-BAENA, O., TOBÓN, J. I., "Microstructural analysis of interfacial transition zone (ITZ) and its impact on the compressive strength of lightweight concretes", Construction and Building Materials, v. 137, n. 15, pp. 381-389, 2017.

[26] KOU, S. C., POON, C. S., "Mechanical properties of 5-year-old concrete prepared with recycled aggregates obtained from three different sources", Magazine of Concrete Research, v. 60, n. 1, pp. 57-64, 2008.

[27] DUAN, Z. H., POON, C. S. "Properties of recycled aggregate concrete made with recycled aggregates with different amounts of old adhered mortars", Materials and Design, v. 58, pp. 19-29, 2014.

[28] BOGAS, J. A., BRITO, J., FIGUEIREDO, J. M., "Mechanical characterization of concrete produced with recycled lightweight expanded clay aggregate concrete", Journal of Cleaner Production. 89 [15], 187195,2015

[29] BENTZ, D. P., "Influence of internal curing using lightweight aggregates on interfacial transition zone percolation and chloride ingress in mortars", Cement \& Concrete Composites, v. 31, pp. 285-289, 2009.

[30] CASTRO, J., Moisture transport in cement based materials: application to transport tests and internal curing. Doctor of philosophy. Purdue University, West Lafayette, Indiana, 2011.

[31] JOCHEM, L. F., ROCHA, J. C., CHERIAF, M., "The influence of fine sand from constructiondemolition wastes (CDW) in the mortar properties", Key Engineering Materials, v. 600, pp. 357-366, 2014.

[32] BENTUR, A., IGARASHI, S., KOVLER, K., "Prevention of autogenous shrinkage in high-strength concrete by internal curing using wet light-weight aggregates", Cement and Concrete Research, v. 31, pp. 1587-1591, 2001.

\section{ORCID}

Lidiane Fernanda Jochem Diego Aponte https://orcid.org/0000-0001-6679-2897

https://orcid.org/0000-0001-5737-7819 
Marilda Barra Bizinotto

Janaíde Cavalcante Rocha https://orcid.org/0000-0002-1417-1615

https://orcid.org/0000-0003-1074-3230 